Buletin Ilmiah Math. Stat. dan Terapannya (Bimaster)

Volume 08, No.4(2019), hal 943-950.

\title{
ANALISIS TEKNIKAL SAHAM LQ-45 MENGGUNAKAN INDIKATOR BOLLINGER BANDS
}

\author{
Nurin Hafizah, Evi Noviani, Hendra Perdana
}

\begin{abstract}
INTISARI
Saham merupakan salah satu bentuk investasi masa kini yang mulai banyak dilirik oleh para investor. Investor yang ingin menanamkan modal di bursa saham sebaiknya mengetahui kekuatan harga saham untuk memprediksi dengan baik pergerakan harga saham di kemudian hari. Analisis teknikal merupakan salah satu teknik yang digunakan dalam melakukan analisis pergerakan harga saham. Terdapat banyak indikator yang dapat digunakan pada analisis teknikal, salah satunya indikator Bollinger Bands. Indikator Bollinger Bands terdiri dari 3 garis Moving Average, yaitu Lower Band (LB), Middle Band $(M B)$ dan Upper Band (UB) serta melibatkan perhitungan volatilitas harga sebuah saham. Tujuan dari penelitian ini untuk menganalisis perhitungan matematis indikator Bollinger Bands dan menentukan sinyal jual dan sinyal beli pada saham. Penelitian ini menggunakan data harian saham yang terdaftar pada saham LQ-45. Data harian saham periode 1 Januari 2018 sampai 31 Desember 2018 digunakan sebagai data training untuk mencari nilai rata-rata return positif dan nilai volatilitas saham lebih besar dari 50\%. Berdasarkan perhitungan maka saham perusahaan Indah Kiat Plup \& Paper (INKP) dapat dianalisis lebih lanjut. Data harian saham periode 1 Januari 2019 sampai 30 April 2019 digunakan sebagai data testing untuk mencari nilai LB, MB dan UB pada saham INKP. Diketahui bahwa sinyal beli dan jual saham pada perusahaan INKP sebanyak 7 sinyal yang diperoleh dari perhitungan Percent Bollinger Bands. Terdapat 3 sinyal untuk menjual saham (bullish), dan 4 sinyal untuk pembelian saham (bearish). Simulasi dilakukan dengan asumsi modal awal sebesar Rp100.000.000,00. Keuntungan terbesar dalam menjual saham pada tanggal 15 Januari 2019 dengan keuntungan sebesar Rp8.253.059,00 (8,25\%), dan keuntungan terkecil pada tanggal 10 Januari 2019 sebesar Rp5.707.472,00 $(5,71 \%)$.
\end{abstract}

Kata Kunci: Moving Average, analisis teknikal, volatilitas saham.

\section{PENDAHULUAN}

Saham merupakan salah satu bentuk investasi masa kini yang mulai banyak diminati oleh para investor. Investor dapat berinvestasi saham menggunakan strategi jangka panjang untuk mendapatkan keuntungan. Saat menanamkan modal di pasar modal sebaiknya investor mengetahui kekuatan harga saham untuk memprediksi dengan baik pergerakan saham tersebut. Indeks yang terdapat di pasar modal digunakan untuk mengukur perubahan harga dari suatu pasar dalam kegiatan perdagangan. Beberapa indeks yang sering digunakan yaitu Indeks Harga Saham Gabungan (IHSG), LQ-45 dan Kompas100. LQ-45 merupakan indeks yang mengukur performa harga 45 saham yang memiliki likuiditas tinggi dan kapitalisasi pasar besar, sehingga memiliki risiko yang kecil untuk mengalami kerugian. Setiap transaksi perdagangan saham, investor dihadapkan kepada pilihan untuk membeli atau menjual saham.

Ada dua macam analisis yang digunakan untuk melakukan investasi saham yaitu analisis fundamental dan analisis teknikal. Analisis fundamental adalah analisis yang bertujuan untuk melakukan penilaian atas saham dengan menggunakan data, perekonomian internasional, perekonomian nasional dan perusahaan [1]. Analisis teknikal adalah studi tentang perilaku pasar yang digambarkan melalui grafik, untuk memprediksi kecenderungan harga di masa yang akan datang [2]. Analisis teknikal dibagi menjadi dua golongan, yaitu analisis teknikal klasik dan analisis teknikal modern. Analisis teknikal klasik mengambil keputusan transaksi berdasarkan pertimbangan (judgment) dan interpretasi penggunanya terhadap grafik. Analisis teknikal modern ditentukan dari perhitungan kuantitatif, bukan interpretasi subjektif terhadap suatu bentuk dan pola grafik. Indikatorindikator pada analisis teknikal modern dikelompokkan ke dalam indikator pengikut tren (trend following indicator) dan indikator oscillator. Indikator pengikut tren digunakan untuk mengetahui 
kekuatan tren, contohnya indikator Average Directional Movement Index, Moving Average, Parabolic SAR dan Bollinger Bands.

Penelitian dalam tulisan ini memfokuskan pada indikator Bollinger Bands yang berguna untuk memberikan informasi apakah pasar sedang ramai atau tenang. Bollinger Bands melibatkan perhitungan volatilitas harga sebuah saham, menggunakan 3 garis Moving Averages yaitu garis batas atas (Upper Band), garis batas tengah (Middle Band), dan garis batas bawah (Lower Band). Moving Averages merupakan indikator yang memantau pergerakan harga rata-rata dalam periode waktu tertentu. Data riwayat pergerakan harga saham ditampilkan sebagai sebuah garis pada chart [3].

Tujuan dari penelitian ini adalah menganalisis perhitungan matematis indikator Bollinger Bands dan menentukan sinyal jual dan sinyal beli saham. Menggunakan data harian pada perusahaan yang terdaftar dalam LQ-45 pada periode 1 Januari 2018 sampai 31 Desember 2018 sebagai data training digunakan untuk mencari nilai return dan volatilitas sebagai proses seleksi saham LQ-45. Sedangkan periode 1 Januari 2019 sampai 30 April 2019 sebagai data testing digunakan untuk perhitungan indikator Bollinger Bands. Seleksi saham dilakukan dengan melihat nilai return yang positif dan nilai volatilitas lebih dari 50\%. Kemudian untuk data saham yang telah lulus seleksi, diamati apakah nilai harga pembukaan (open) lebih besar sama dengan harga penutupan (close) yang artinya menunjukan sinyal harga saham akan turun (bearish). Begitu juga saat nilai open lebih kecil sama dengan harga close maka akan menunjukkan sinyal harga saham akan naik (bullish).

Parameter yang digunakan dalam perhitungan indikator Bollinger Bands berupa periode $(n)$ dan nilai $k$ yang ditentukan oleh peneliti (trader). Nilai Standar menurut John Bollinger, yaitu $n=20$ dan $k=2$. Setelah menentukan nilai $n$ dan $k$ dilanjutkan dengan mencari nilai Simple Multi Average pada periode ke- $n$ dan waktu ke- $t\left(S M A(n)_{t}\right)$. Selanjutnya menentukan nilai volatilitas dalam Bollinger Bands $\left(\sigma_{B(n)}\right)$. Nilai volatilitas yang tinggi menunjukkan pergerakan turun dan naiknya harga saham. Bollinger Bands periode ke- $n$ pada waktu ke- $t$ mempunyai 3 grafik garis batas berupa Upper Band $\left(U B(n)_{t}\right)$, Middle Band $\left(M B(n)_{t}\right)$ dan Lower Band $\left(L B(n)_{t}\right)$ yang berfungsi untuk mengetahui arah pergerakan saham.

Percent Bollinger Bands periode ke- $n$ pada waktu ke- $t, P B B(n)_{t}$ merupakan sebuah indikator yang didapat dari pergerakan garis elastis Upper Band dan Lower Band. Proses akan terus berlanjut sampai $t$ mencapai nilai maksimal, selanjutnya mengambil keputusan dalam jual atau beli saham. Apabila nilai dari PBB lebih dari 1, maka pergerakan harga berada di atas garis elastis Upper Band, yang menunjukkan sinyal sell. Apabila nilai PBB kurang dari 0, maka pergerakan harga berada di bawah garis elastis Lower Band yang menunjukkan sinyal buy.

\section{SAHAM}

Saham merupakan tanda penyertaan modal seseorang atau pihak (badan usaha) dalam suatu perusahaan atau perseroan terbatas. Seseorang atau sebuah organisasi yang memiliki saham disebut pemegang saham (stock holder). Dalam aktivitas perdagangan saham sehari-hari, harga saham mengalami fluktuasi baik berupa kenaikan maupun penurunan. Pembentukan harga saham terjadi karena adanya permintaan (supply) dan penawaran (demand) atas saham tersebut.

Penawaran dan permintaan terjadi karena adanya faktor yang sifatnya spesifik seperti kinerja perusahaan dan industri dimana perusahaan tersebut bergerak. Faktor yang sifatnya makro seperti tingkat suku bunga, inflasi, nilai tukar mata uang dan faktor-faktor non-ekonomi seperti kondisi sosial dan politik, dan faktor lainnya [4].

Ada beberapa istilah mengenai harga yang sering digunakan dalam perdagangan saham yaitu:

1. High, yaitu harga saham tertinggi pada suatu periode perdagangan.

2. Low, yaitu harga saham terendah pada suatu periode perdagangan.

3. Open, yaitu harga awal saham pada saat pembukaan bursa dalam suatu periode perdagangan.

4. Close, yaitu harga akhir saham pada saat penutupan bursa dalam suatu periode perdagangan.

5. Volume, yaitu jumlah lembar saham yang diperdagangkan dalam suatu periode perdagangan. 


\section{ANALISIS TEKNIKAL}

Analisis teknikal merupakan pengkajian data pasar yang lampau terutama harga dan volume untuk memprediksi tren suatu harga saham dan sinyal perdagangan. Hasil dari analisa teknikal ini nantinya dapat digunakan untuk membantu membuat keputusan dalam melakukan perdagangan atau berinvestasi [5].

Beberapa informasi penting dilakukannya analisis teknikal, antara lain [3].

1. Support dan resistance level

Support adalah kisaran harga di mana pada level atau kisaran tersebut diperkirakan permintaan cukup kuat untuk dapat menahan harga jatuh lebih lanjut. Logika sederhananya adalah ketika harga turun mendekati kisaran support, menyebabkan meningkatnya keinginan investor untuk membeli saham. Resistance adalah tingkat harga dimana kecenderungan menjual pada kisaran tersebut diperkirakan cukup kuat untuk menahan laju kenaikan harga. Logika dasarnya adalah bahwa jika terjadi kenaikan harga yang mendekati kisaran resistance, maka kecenderungan investor untuk menjual semakin meningkat.

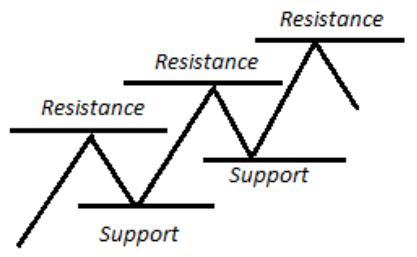

Gambar 1 Resistance dan Support

Seperti yang dapat dilihat pada Gambar 1 terdapat pola zig-zag yang menunjukkan pergerakan menanjak, ketika pasar bergerak ke atas dan kemudian kembali ke bawah, maka titik tertinggi yang dicapai sebelum harga kembali turun adalah resistance. Kemudian, ketika harga naik kembali, maka titik terendah yang dicapai sebelum harga kembali naik disebut support.

2. Tren Pasar

Tren adalah pola kecenderungan pergerakan harga saham kearah tertentu dari waktu ke waktu. Perdagangan saham dikenal dengan tiga tren yaitu, tren kenaikan (uptrend), tren penurunan (downtrend), dan kondisi biasa (sideways), hal ini dapat dilihat pada Gambar 2. Kondisi uptrend terjadi ketika harga mencapai puncak yang lebih tinggi dan juga lembah yang tinggi dalam grafik. Downtrend sendiri terjadi ketika harga menyentuh lembah yang lebih rendah dan puncak yang lebih rendah dalam grafik. Sedangkan sideways atau flattrend terjadi ketika harga perdagangan dalam rentang tertentu tanpa adanya pergerakan ke atas maupun ke bawah secara signifikan.

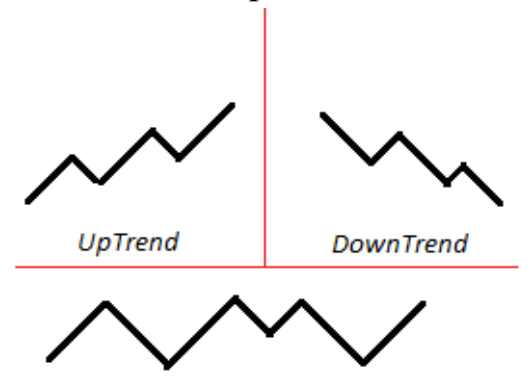

Sideways

Gambar 2 Tren pasar

\section{INDIKATOR TEKNIKAL}

Indikator teknikal merupakan satu rangkaian titik data yang dihasilkan dari penggunaan satu formula atas data-data harga saham tertentu. Data-data harga yang digunakan dalam analisa teknikal meliputi berbagai kombinasi dari harga open, high, low dan close selama periode waktu tertentu.

Indikator lebih banyak menggunakan harga saham sebagai masukan untuk perhitungannya dan biasanya yang digunakan adalah harga close saham pada suatu perdagangan. 
Tiap-tiap indikator berguna dalam cara yang berbeda dari pada waktu yang berbeda. Penggunaan indikator dapat membantu kita untuk mengindentifikasi [6]:

1. Arah tren

2. Kekuatan sebuah tren

3. Tingkat support dan resistance dalam tren pada suatu perdagangan

4. Divergence, adalah perbedaan antara indikator dan harga yang menunjukkan kemungkinan pembalikan tren di masa depan

5. Konfirmasi pembalikan tren

\section{CANDLESTICK CHART}

Grafik dibentuk dari data runtun waktu, sumbu $Y$ (sumbu vertikal) menunjukkan skala harga dan sumbu $X$ (sumbu horizontal) menunjukkan skala waktu. Harga diplot dari kiri ke kanan sepanjang sumbu $X$ di mana plot data terbaru berada di sisi kanan. Grafik dapat dikatakan sebagai alur sejarah pergerakan harga dari waktu ke waktu [4].

Grafik lilin atau dalam istilah umum dikenal dengan candlestick chart merupakan metode yang paling banyak digunakan untuk mempresentasikan pergerakan nilai saham. Candlestick umumnya digunakan untuk perdagangan jangka pendek, sehingga lebih cocok digunakan oleh trader. Kelebihan candlestick ini adalah mampu menampilkan psikologi pasar.

Candlestick pada Gambar 3 dapat memperlihatkan empat nilai sekaligus, yaitu harga pembukaan (open), harga penutupan (close), harga tertinggi (high), dan harga terendah (low) dalam suatu periode waktu tertentu. Ada dua warna yang digunakan, misalnya merah dan hijau. Candlestick berwarna hijau menunjukkan harga close lebih tinggi dari harga open (positif), sedangkan warna merah adalah sebaliknya (negatif).

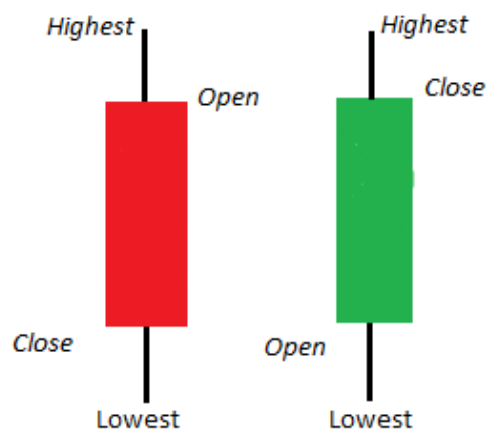

Gambar 3 Candlestick

\section{RETURN SAHAM, SIMPLE MOVING AVERAGE dan VOLATILITAS}

Return saham dapat diartikan sebagai tingkat imbal hasil (tingkat keuntungan) yang diperoleh sebagai akibat dari investasi yang dilakukan. Nilai dari return bisa positif maupun negatif tergantung kondisi real dari aset investasi. Return harian dapat diperoleh melalui persamaan berikut [7]:

$$
R(n)_{t}=\ln \left(\frac{X(n)}{X(n-t)}\right)
$$

$X(n) \quad$ : Data saham pada periode ke- $n$

Simple Moving Average (SMA) merupakan varian dari Moving Average (MA) yang mencerminkan harga rata-rata dari nilai pergerakan suatu saham di dalam waktu tertentu secara sederhana. Rentang waktu atau periode yang dimaksud sesuai dengan setting yang di tentukan trader. SMA periode ke- $n$ pada waktu ke- $t$ yaitu:

$$
\operatorname{SMA}(n)_{t}=\frac{X_{n+t}+X_{n-1+t}+\ldots+X_{2+t}+X_{1+t}}{n}=\bar{X}(n)_{t}
$$


SMA $(n)_{t} \quad$ : Simple Moving Average pada periode ke- $n$ waktu ke- $t$

$\bar{X}(n)_{t} \quad$ : Rata-rata harga saham pada periode ke- $n$ waktu ke- $t$

Volatilitas dalam Bollinger Bands dinyatakan dengan $\sigma_{B(n) t}$, yaitu standar deviasi dari data pada periode ke- $n$ waktu ke-t. Didefinisikan volatilitas Bollinger Bands yaitu [8]:

$$
\sigma_{B(n)_{t}}=\sqrt{\frac{\sum_{i=1}^{n}\left(X_{i+t}-\bar{X}(n)_{t}\right)^{2}}{n}}
$$

Nilai volatilitas berada pada interval yang positif , yaitu antara 0 sampai dengan $\infty(0 \leq \sigma \leq \infty)$. Nilai volatilitas yang tinggi menunjukkan bahwa harga saham berubah (naik dan turun). Sedangkan volatilitas dikatakan rendah jika harga saham tidak banyak berubah atau cenderung konstan.

\section{INDIKATOR BOLLINGER BANDS}

Bollinger Bands adalah indikator yang diperkenalkan oleh John Bollinger pada tahun 1983. Bollinger Bands adalah indikator teknikal yang bekerja dengan dua garis batas (band) dan sebuah garis batas tengah yang bergerak mengikuti rata-rata pergerakan harga sepanjang periode tertentu Garis batas tengah disebut Middle Band (MB), batas atas disebut Upper Band (UB) dan batas bawah disebut Lower Band (LB). Diberikan $N$ data harga saham $X_{1}, X_{2}, \ldots, X_{N}$ bila $\sigma^{2}$ tidak diketahui, maka grafik batas Bollinger Bands dari SMA periode $n$ pada waktu ke- $t$ adalah:

$$
\begin{aligned}
L B(n)_{t} & =\bar{X}(n)_{t}-k \sigma_{B(n)_{t}} \\
M B(n)_{t} & =\bar{X}(n)_{t} \\
U B(n)_{t} & =\bar{X}(n)_{t}+k \sigma_{B(n)_{t}}
\end{aligned}
$$

\section{PERCENT BOLLINGER BANDS}

Percent Bollinger Bands (PBB) merupakan sebuah indikator yang didapat dari pergerakan garis elastis upper band dan lower band dengan pergerakan harga. Indikator ini digunakan untuk mengetahui keberadaan pergerakan harga terhadap upper, lower dan middle band. PBB pada waktu ke- $t$ sebagai berikut:

$$
P B B(n)_{t}=\frac{X_{t}-L B(n)_{t}}{\left(U B(n)_{t}-L B(n)_{t}\right)}
$$

Apabila nilai dari PBB lebih dari 1, maka pergerakan harga berada di atas garis elastis upper band. Sedangkan jika nilai PBB kurang dari 0, maka pergerakan harga berada di bawah garis elastis lower band. Saat nilai PBB adalah 0,5 maka pergerakan harga berada di garis middle band.

\section{SISTEM PERDAGANGAN BOLLINGER BANDS}

Sistem perdagangan Bollinger Bands (BB) adalah sebagai berikut [8]:

1. Analisis pergerakan harga saham menggunakan candlestick chart, karena chart ini lebih mudah dalam membaca sinyal tren yang sedang terjadi.

2. Indikator yang digunakan adalah Bollinger Bands.

3. Keputusan beli (buy) dilakukan apabila nilai PBB hari kemarin di bawah garis 0, artinya harga close berada di bawah garis elastis lower band.

4. Keputusan jual (sell) dilakukan apabila nilai PBB hari kemarin di atas garis 1, artinya harga close berada di atas garis elastis upper band

\section{STUDI KASUS}

Pada penelitian ini data yang digunakan dalam penelitian ini merupakan data sekunder yang diperoleh dari data harian saham yang terdaftar pada saham LQ-45. Sumber data yang digunakan didapat dari yahoo.finance.com. Data harian saham yang digunakan dengan periode 1 Januari 2018 
sampai 30 April 2019. Data harian saham periode 1 Januari 2018 sampai 31 Desember 2018 digunakan sebagai data training, sedangkan data periode 1 Januari 2019 sampai 30 April 2019 digunakan sebagai data testing.

Dari daftar saham LQ-45 akan dilakukan seleksi saham dengan melihat nilai rata-rata return harian saham bernilai positif dan nilai volatilitas bernilai lebih dari 50\%. Perhitungan nilai rata-rata return harian saham dan volatilitas menggunakan Persamaan (1) dan Persamaan (2) yang lulus seleksi hasilnya dapat dilihat pada Tabel 1 .

Tabel 1 Nilai rata-rata return dan volatilitas saham

\begin{tabular}{cccccccc}
\hline No. & $\begin{array}{c}\text { Kode } \\
\text { Saham }\end{array}$ & $\begin{array}{c}\text { Return } \\
\text { Saham }\end{array}$ & Volatilitas & No. & $\begin{array}{c}\text { Kode } \\
\text { Saham }\end{array}$ & $\begin{array}{c}\text { Return } \\
\text { Saham }\end{array}$ & Volatilitas \\
\hline 1 & ANTM & $0,078 \%$ & $43,92 \%$ & 7 & INKP & $0,292 \%$ & $61,23 \%$ \\
2 & BBCA & $0,066 \%$ & $22,37 \%$ & 8 & PGAS & $0,074 \%$ & $60,15 \%$ \\
3 & BBRI & $0,002 \%$ & $34,69 \%$ & 9 & PTBA & $0,215 \%$ & $42,33 \%$ \\
4 & BRPT & $0,021 \%$ & $38,64 \%$ & 10 & SMGR & $0,058 \%$ & $43,77 \%$ \\
5 & ICBP & $0,062 \%$ & $25,62 \%$ & 11 & WIKA & $0,025 \%$ & $42,63 \%$ \\
6 & INCO & $0,046 \%$ & $46,31 \%$ & & & & \\
\hline
\end{tabular}

\section{ANALISIS BOLLINGER BANDS SAHAM INKP}

Setting standar yang direkomendasikan oleh John Bollinger adalah 20-2, artinya menggunakan SMA-20 dengan nilai $k$-2 merupakan tingkat kepercayaan 95\%. Proses Perhitungan $\operatorname{SMA}(n)_{t}$ dengan menggunakan Persamaan (3) dan Persamaan (2) untuk menghitung $\sigma_{B(n)_{t}}$. Selanjutnya menghitung $L B(n)_{t}$ dengan menggunakan Persamaan (4), $M B(n)_{t}$ menggunanakan Persamaan (5) $U B(n)_{t}$ dan menggunakan Persamaan (6). Selanjutnya mencari nilai $P B B(n)_{t}$ dengan Persamaan (7) dengan $n=20$ hasil perhitungannya dapat dilihat pada Tabel 2.

Tabel 2 Nilai Perhitungan $S M A(20)_{t}, \sigma_{B(20)_{t}}, L B(20)_{t}, M B(20)_{t}, U B(20)_{t}$ dan $P B B(20)_{t}$

\begin{tabular}{ccccccc}
\hline $\boldsymbol{t}$ & $\boldsymbol{S M A}(\boldsymbol{n})_{\boldsymbol{t}}$ & $\sigma_{B(n)_{\boldsymbol{t}}}$ & $\boldsymbol{L B}(\mathbf{2 0})_{\boldsymbol{t}}$ & $\boldsymbol{M B ( 2 0 ) _ { \boldsymbol { t } }}$ & $\boldsymbol{U B}(\mathbf{2 0})_{\boldsymbol{t}}$ & $\boldsymbol{P B B}(\boldsymbol{n})_{\boldsymbol{t}}$ \\
\hline 0 & 11637,500 & 259,744 & 11118,011 & 11637,500 & 12156,989 & 0,416 \\
1 & 11632,500 & 261,461 & 11109,578 & 11632,500 & 12155,422 & 0,373 \\
2 & 11620,000 & 271,400 & 11077,200 & 11620,000 & 12162,800 & 0,205 \\
$\vdots$ & $\vdots$ & $\vdots$ & $\vdots$ & $\vdots$ & $\vdots$ & $\vdots$ \\
61 & 10131,250 & 724,382 & 8682,487 & 10131,250 & 11580,013 & 0,222 \\
62 & 10047,500 & 712,340 & 8622,821 & 10047,500 & 11472,179 & 0,255 \\
63 & 9922,500 & 723,337 & 8475,825 & 9922,500 & 11369,175 & 0,069 \\
\hline
\end{tabular}

Gambar 4 merupakan candlestick dari hasil perhitungan $L B(20)_{t}, M B(20)_{t}, U B(20)_{t}$ pada 4 bulan terakhir dapat dilihat dalam bentuk grafik candlestick. Candlestick berwarna merah berarti harga close lebih rendah dari harga open yang menunjukkan sinyal harga saham akan turun (bearish). Sedangkan untuk candlestick berwarna hijau berarti harga close lebih tinggi dari harga open yang menunjukkan sinyal harga saham akan naik (bullish).

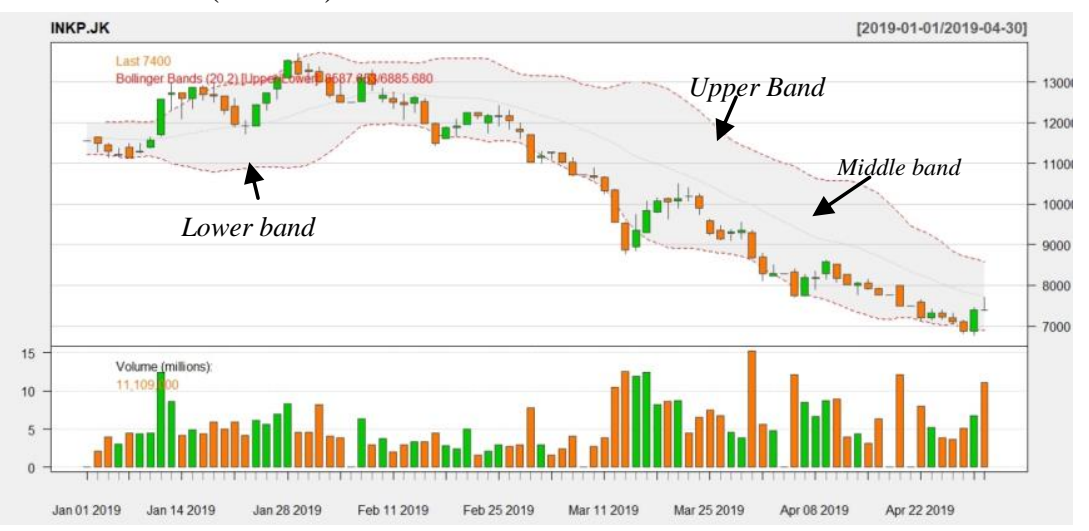

Gambar 4 Grafik candlestick saham INKP menggunakan Bollinger Bands 

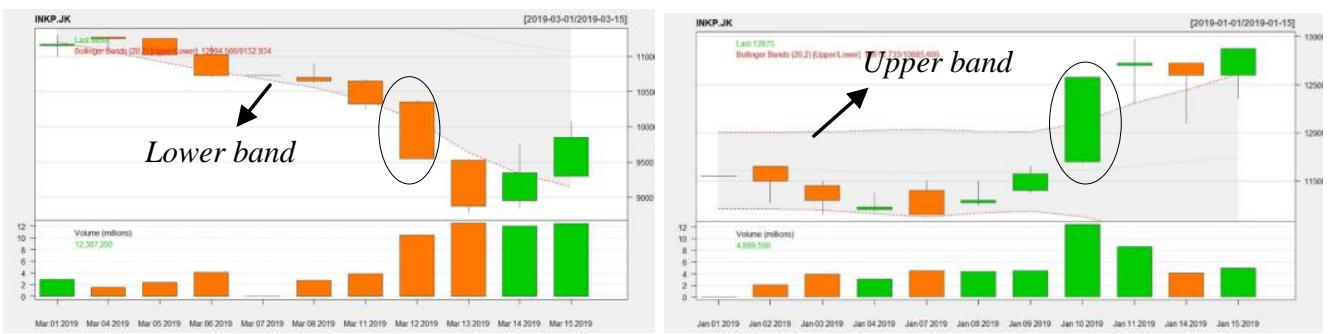

Gambar 5 Candlestick bearish dan candlestick bullish

Gambar 5, tanggal 12 Maret 2019 saat itu candlestick bearish (merah) menyentuh garis lower band pertanda telah terjadi keadaan jenuh jual (oversold) yang berarti disarankan untuk membeli saham. Saat candlestick bearish (hijau) menyentuh garis upper band seperti gambar 5, maka keputusan yang harus diambil pada saat itu adalah menjual saham dikarenakan terjadinya keadaan jenuh beli (overbought).

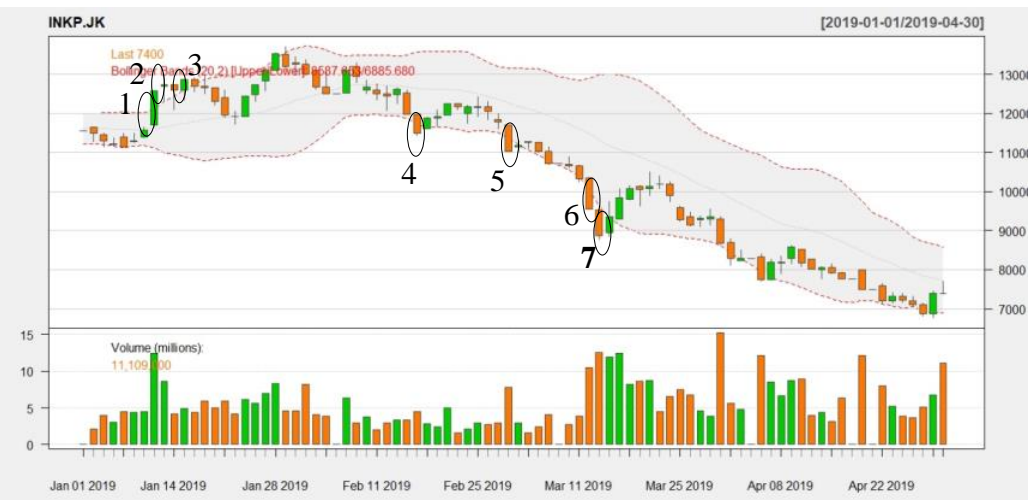

Gambar 6 Grafik candlestick sinyal saham INKP menggunakan Bollinger Bands

Keputusan jual dan beli saham dilakukan dengan melihat nilai $P B B$ saham tersebut. Jika $P B B$ kurang dari 0, maka keputusan untuk buy saham sedangkan untuk nilai $P B B$ lebih dari 1 maka keputusan untuk sell saham. Gambar 6 pada sinyal nomor 1, tanggal 10 Januari 2019 menunjukkan sinyal bullish, karena harga close lebih tinggi dari harga open dan candlestick menyentuh garis upper band. Memiliki nilai PBB 1,226 artinya waktu yang tepat untuk sell saham. Selanjutnya tanggal 11 Januari 2019 pada sinyal nomor 2, sinyal bullish kembali muncul artinya sell saham pada waktu tersebut. Sinyal bullish terakhir terdapat pada sinyal nomor 3 tanggal 15 Januari 2019, saham juga dapat di sell pada saat ini.

Sinyal nomor 4 pada tanggal 15 Februari 2019 menunjukkan sinyal bearish, candlestick menyentuh garis lower band. Nilai $P B B$ sebesar -0,051 artinya waktu yang tepat untuk buy saham. Selanjutnya sinyal bearish terdapat pada tanggal 28 Februari 2019 sinyal nomor 5, 12 Maret 2019 sinyal nomor 6 dan 13 Maret 2019 sinyal nomor 7, candlestick menyentuh garis lower band saham juga dapat dibeli pada waktu tersebut.

\section{SIMULASI TRANSAKSI}

Visualisasi sebagian transaksi saham dengan performa sistem BB $(20,2)$ selama 4 bulan terakhir dapat dilihat pada Tabel 3.

Tabel 3 Simulasi Transaksi Perdagangan Saham Menggunakan BB $(20,2)$

\begin{tabular}{|c|c|c|c|c|c|c|c|c|}
\hline No & Saham & Tanggal Beli & Harga Beli & No & Tanggal Jual & Harga Jual & Laba & Laba (\%) \\
\hline 1 & 8.571 & $1 / 1 / 2019$ & Rp99.995.050,00 & 1 & $1 / 10 / 2019$ & Rp107.780.325,00 & Rp5.707.472,00 & $5,71 \%$ \\
\hline 2 & 8.571 & $1 / 1 / 2019$ & Rp99.995.050,00 & 2 & $1 / 11 / 2019$ & Rp109.065.975,00 & Rp6.980.265,00 & $6,98 \%$ \\
\hline 3 & 8.571 & 1/1/2019 & Rp99.995.050,00 & 3 & $1 / 15 / 2019$ & Rp1 10.351.625,00 & Rp8.253.059,00 & $8,25 \%$ \\
\hline 4 & 8.267 & 2/15/2019 & Rp99.997.325,00 & & & & & \\
\hline 5 & 8.461 & $2 / 28 / 2019$ & Rp99.993.700,00 & & & & & \\
\hline 6 & 9.565 & $3 / 12 / 2019$ & Rp99.997.750,00 & & & & & \\
\hline 7 & 10.393 & $3 / 13 / 2019$ & Rp99.993.325,00 & & & & & \\
\hline
\end{tabular}


Diasumsikan pembelian dilakukan pada awal tahun, pada tanggal 1 Januari 2019 dengan modal awal Rp100.000.000,00. Jumlah saham yang dapat dibeli sebanyak 8.571 saham, biaya pembelian saham sebesar Rp99.995.050,00. Dengan menggunakan indikator Bollinger Bands didapat sinyal penjualan pada tanggal 10 Januari 2019, 11 Januari 2019 dan 15 Januari 2019. Tanggal 10 Januari harga jual saham sebesar Rp107.780.325,00 dan mendapatkan laba Rp.5.707.472,00 (5,71\%) tanggal 11 Januari harga jual saham sebesar Rp.109.065.975,00 dan mendapatkan laba Rp6.980.265,00 (6,98\%). Terakhir pada tanggal 15 Januari harga jual saham sebesar Rp110.351.625,00 (8,25\%). Kesimpulan penjualan sebaiknya dilakukan pada tanggal 15 Januari 2019 yang memiliki laba paling besar 8,25\% sebesar Rp110.351.625,00.

Selanjutnya terdapat sinyal pembelian pada tanggal 15 Februari, 28 Februari, 12 Maret, dan 13 Maret 2019. Saham yang dapat dibeli pada tanggal 15 Februari sebanyak 8.267 saham, pada tanggal 28 Februari sebanyak 8.461 saham. Bulan Maret terdapat dua sinyal pembelian pada tanggal 12 Maret sebanyak 9.565 saham dan tanggal 13 Maret sebanyak 10.393 saham.

\section{PENUTUP}

Bollinger Bands merupakan indikator teknikal yang bekerja dengan nilai volatilitas saham. Menggunakan ketentuan yang di setting oleh John Bollinger untuk SMA-20 dan k-2, maka Upper Band dan Lower Band yang dihasilkan pada saham INKP memiliki volatilitas yang masih bergerak diantar kedua bands tersebut. Sinyal beli dan jual saham pada perusahaan Indah Kiat Plup \& Paper Tbk (INKP) sebanyak 7 sinyal. Terdapat 3 sinyal untuk menjual saham (bullish) yaitu pada tanggal 10 Januari, 11 Januari dan 15 Januari 2019. Sedangkan 4 sinyal untuk melakukan pembelian saham (bearish) yaitu pada tanggal 15 Februari, 28 Februari, 12 Maret dan 13 Maret 2019. Simulasi pada studi kasus untuk 4 bulan terakhir (Januari-April) dengan asumsi modal awal sebesar Rp.100.000.000,00 pembelian saham dilakukan pada tanggal 1 Januari 2019. Keuntungan terbesar dalam menjual saham pada tanggal 15 Januari 2019 dengan keuntungan sebesar Rp8.253.059,00 (8,25\%), pada tanggal 11 Januari 2019 dengan keuntungan sebesar Rp6.980.265,00 (6,98\%) dan keuntungan terkecil pada tanggal 10 Januari 2019 sebesar Rp5.707.472,00 (5,71\%).

\section{DAFTAR PUSTAKA}

[1] Syamsir, H. Solusi Investasi di Bursa Saham Indonesia Pendekatan Analisa Teknikal Melalui Studi Kasus Riil dengan Dilengkapi Formulasi Metastock. Jakarta: PT Elex Media Komputindo. 2004.

[2] Murphy, J. J. Technical Analysis of the Financial Markets. New York: New York Institute of Finance. 1999.

[3] Ong, E. Technical Analysis for Mega Profit. Jakarta: MegaOptions. 2011.

[4] Hendarto, K. Belajar Tranding. Yogyakarta: Andi. 2005.

[5] Indonanjaya, K dan Sukardi, K. Pendekatan Teknikal dan Fundamental untuk Analisis Saham. Yogyakarta: Graha Ilmu. 2010.

[6] Stevens, L. Essential Technical Analysis - Tools and Techniques to Spot Market Trends. John Wiley \& Son. 2002.

[7] Wira, D. Analisis Teknikal untuk Profit Maksimal. Jakarta: Exceed. 2015.

[8] Sulistiawan, D dan Liliana. Analisis Teknikal Modern pada Perdagangan Sekuritas. Yogyakarta: Andi. 2007.

NURIN HAFIZAH

EVI NOVIANI

HENDRA PERDANA
: Jurusan Matematika FMIPA UNTAN, Pontianak nurinhafizah10@student.untan.ac.id

: Jurusan Matematika FMIPA UNTAN, Pontianak evi_noviani@math.untan.ac.id : Jurusan Matematika FMIPA UNTAN, Pontianak hendra.perdana@math.untan.ac.id 
